The Egyptian Journal of Hospital Medicine (October 2018) Vol. 73 (9), Page 7435-7443

\title{
Immunohistochemical Study of Epithelial Mesenchymal Transition Markers Slug and E-Cadherin in Laryngeal Squamous Cell Carcinoma
}

\author{
Laila Abd El-Samea Moussa, Marwa Abd Al Moniem Al Kholy, Azza Kamal Taha \\ Department of Pathology, Faculty of Medicine, Al-Azhar University, Egypt \\ Corresponding author: Azza Kamal Taha, Email: azakamal.medg@azhar.edu.eg
}

\begin{abstract}
Background: laryngeal carcinoma is the most common head and neck cancer, with a high rate of metastasis and poor prognosis. It has a global incidence of 3.2 cases per 100,000 and a death rate of 1.1 per 100,000 per annum. Squamous cell carcinomas constitute more than $95 \%$ of primary cancer larynx. Despite of the recent advances in the treatment modalities for laryngeal carcinoma, the survival rate of patients with this malignancy has not improved significantly. Therefore, there is an urgent need to identify novel biomarkers for the prediction of tumour progression and metastasis. Epithelial-mesenchymal transition (EMT) process promotes the aggressive behaviour of cancer through downregulation of epithelial markers and upregulation of mesenchymal markers of cancer cells in order to become motile and invasive. Several transcription factors are key regulators of EMT, including the Snail/Slug family, Twist, ZEB1 and ZEB2.

Aim of the work: this study aimed to evaluate the immunohistochemical (IHC) expression of the transcription factor Slug as an inducer of EMT and E-cadherin as an epithelial protein in 50 Egyptian cases of laryngeal squamous cell carcinoma (LSCC) and investigation of the relationship between both markers and the clinicopathologic parameters. Material and Method: the material of this study included 50 specimens of LSCC. All specimens were embedded in paraffin and stained with Hematoxilin and Eosin (H \& E) for histopathological evaluation. Other Sections were immunostained with antibodies to Slug and E-Cadherin. The results were tabled, statistically analyzed and discussed. Results: high tumor grade and high TNM stage were positively correlated with Slug IHC expression (P-value $=0.02$ and 0.001 ) but inversely correlated with E-cadherin IHC expression (pvalue $=0.006$ and 0.03) respectively. Conclusion: LSCC patients with Slug IHC overexpression and reduced Ecadherin IHC expression are at higher risk of metastatic carcinoma and might benefit from more aggressive treatment after surgery.
\end{abstract}

Keywords: LSCC, EMT, Slug, E-cadherin.

\section{Introduction}

Laryngeal cancer is the most common head and neck cancer in the world with a high mortality rate and poor prognosis ${ }^{[1]}$. More than $95 \%$ of all malignant tumors in the larynx are squamous cell carcinoma ${ }^{[2]}$. It accounts for $5.7 \%$ to $7.6 \%$ of systemic malignant cancers. The morbidity of laryngeal cancer has increased significantly in recent years. Although major progress has been achieved in the treatment of laryngeal cancer, the long-term survival rate of patients with laryngeal cancer still not increased significantly. ${ }^{[3]}$ There are currently no markers for assessing prognosis or tumor behavior in LSCC. Therefore, it is worthwhile to investigate biomarkers for understanding tumor behavior and for guidance to optimal treatment ${ }^{[1]}$.Invasion and metastasis are the main factors affecting a patient's overall survival and quality of life ${ }^{[4]}$. Once occurring the lymph node metastasis, the 5-year survival rate of laryngeal cancer patients may be less than $50 \%$, and the 5-year survival rate may be less than $20 \%$ when distant metastasis occurred ${ }^{[5]}$. Approximately $90 \%$ of cancer deaths are caused by metastasis, yet it remains the most poorly understood component of cancer pathogenesis because of its complexity. Emerging evidence suggests that epithelialmesenchymal transition (EMT), which is an essential phenotypic conversion during embryonic development, tissue remodeling, and wound healing, plays an important role in cancer metastasis. During EMT, epithelial cells acquire fibroblast-like properties, exhibit reduced intercellular adhesion and show increased motility. Several transcription factors are key regulators of EMT, including the Snail/Slug family, Twist, ZEB1 and ZEB2 ${ }^{[6]}$.Slug, also known as Snail2, is one of the key transcription factors that activate EMT process in cancer progression. It contributes to repression of the epithelial phonotype by binding to E-box DNA sequences in the proximal promoter region of the Ecadherin gene. This role as a strong E-cadherin 
Immunohistochemical Study of Epithelial Mesenchymal Transition Markers Slug and E-Cadherin...

repressor mediates loss of tight junctions of epithelial cells and initiates EMT, which facilitates cancer cell invasion and distant metastasis ${ }^{[7]}$. Ecadherin is a cell adhesion molecule located in the cell adhesion site of epithelial cells; it plays an important role in the suppression of tumor invasion. When E-cadherin is decreased or inactivated, the malignant potential of tumors is increased and metastasis is induced. ${ }^{[8]}$

\section{Materials and Methods}

The material of this work included 50 paraffin blocks of LSCC cases that had been retrieved retrospectively from the Pathology Department of Kasr El-Ainy Hospital, National Cancer Institute, Cairo University and Al Zahraa Hospital, Al Azhar University, within the period from October 2016 to March 2018. The clinical information of the patients was obtained from their pathology reports and patient charts.

The study protocol was approved by the Ethical Committee of the Faculty of Medicine, AlAzhar University.Four micron $(\mu \mathrm{m})$ thick serial sections were cut from paraffin blocks of all cases and stained with Hematoxylin and Eosin (H\&E); all cases were re-evaluated and tumours were graded according to modified Broder's grading system as grade I ( 5 cases), grade II (33 cases) and grade III (12 cases). Other sections were cut and placed on charged poly-L-lysine pre-treated glass slides then taken for immunohistochemical staining as follows: for mouse monoclonal antibodies against SLUG (Santa Cruz Biotechnology Inc, Europe; A-7), normal gastric epithelial cells was used as an external positive control and for mouse monoclonal antibodies against E-Cadherin (Dako, USA, $\mathrm{NCH} 38$ ), breast duct carcinoma was used as an external positive control. For both markers negative-control staining was done by omitting the primary antibodies. Avidin-Biotin immunoperoxidase Complex technique $(\mathrm{ABC})$ was used.

The whole sections were scanned and evaluated at $10 \mathrm{x}$ magnification of the light microscope. Nuclear staining was considered for Slug, membranous staining was considered for Ecadherin. For Slug expression, the cases were scored as high and low Slug expressors according to the intensity and percentage of positive tumor cells as follows: the percentage of positive tumor cells was assigned to one of the following categories: $0(<5 \%)$, 1 (5-25\%); 2 (26-50\%), $3(51-75 \%)$ and 4(

\section{Aim of the work}

This study aimed to evaluate the immunohistochemical (IHC) expression of the transcription factor Slug as an inducer of EMT and E-cadherin as an epithelial protein in laryngeal squamous cell carcinoma (LSCC) and investigation of the relationship between both markers and the clinicopathologic parameters.

$>75 \%)$. The intensity of Slug immunostaining was scored as follows: $1+$ (weak); $2+$ (moderate) and 3+ (intense). Then the percentage of positive tumor cells and the staining intensity were multiplied to produce a score for each case. Cases with a Slug score $\geq 2$ were considered to exhibit high expression ${ }^{[6]}$. For E-cadherin expression, the cases were scored as retained and reduced E-cadherin expressors according to the percentage of positive tumor cells. The staining was considered "reduced", if $<50 \%$ of tumor cells were positive for membranous staining ${ }^{[9]}$.Data management and analysis were performed using statistical analysis Systems. Data were summarized using means and standard deviations. Categorical data were summarized as percentages. Comparisons between groups with respect to numeric variables were done using the Mann-Witney nonparametric test. Comparisons between categorical variables were done by the Chisquare test. P-values $<0.05$ were considered significant.

\section{Results}

Age of patients was ranged from 32 to 75 years, with a mean age of $57.7 \pm 9.74 \mathrm{SD}$. There were 48 male and 2 female patients, with male to female ratio: 12:1.

Tumor anatomical site was classified into four categories: supraglottic tumors (14 cases), glottic tumors (12 cases), subglottic tumors (3 cases) and transglottic tumors (21 cases). Laryngeal carcinomas were graded according to modified Broders' grading system as grade I (5 cases), grade II (33 cases) and grade III (12 cases). In this study, 4 cases were pT1, 18 cases were pT2, 17 cases were pT3 and 11 cases were pT4a. Lymph node metastases were found in 23 cases. According to the criteria of the AJCC TNM (2017) staging protocol of laryngeal carcinoma, 2 cases were diagnosed as stage I, 15 cases as stage II, 12 cases as stage III and 21 cases as stage Iva. No cases were diagnosed in stages IVb or IVc (Table 1). 
Table 1: clinical data of patients included in this study

\begin{tabular}{|c|c|}
\hline Characteristics & NO. $(\%)$ \\
\hline $\begin{array}{l}\text { Age category } \\
\quad \cdot<60 \\
\cdot>60\end{array}$ & $\begin{array}{ll}21 & (42 \%) \\
29 & (58 \%)\end{array}$ \\
\hline $\begin{array}{l}\text { Sex } \\
\cdot \text { Male } \\
\cdot \text { Female }\end{array}$ & $\begin{array}{ll}48 & (96 \%) \\
2 & (4 \%)\end{array}$ \\
\hline $\begin{array}{l}\text { Primary site } \\
\text { - Supraglottic } \\
\text { - Glottic } \\
\text { - Subglottic } \\
\text { - Transglottic }\end{array}$ & $\begin{array}{ll}14 & (28 \%) \\
12 & (24 \%) \\
3 & (6 \%) \\
21 & (42 \%)\end{array}$ \\
\hline $\begin{array}{l}\text { Histological grade } \\
\text { - GI } \\
\text { - GII } \\
\text { - GIII }\end{array}$ & $\begin{array}{ll}5 & (10 \%) \\
33 & (66 \%) \\
12 & (24 \%)\end{array}$ \\
\hline $\begin{array}{l}\text { T-stage } \\
\cdot \text { T1 } \\
\cdot \text { T2 } \\
\cdot \text { T3 } \\
\cdot \text { T4 }\end{array}$ & $\begin{array}{l}(8 \%) \\
(36 \%) \\
(34 \%) \\
(22 \%)\end{array}$ \\
\hline $\begin{array}{l}\text { Lymph node metastasis } \\
\cdot \text { N0 } \\
\cdot \text { N1 } \\
\cdot \text { N2b } \\
\cdot \text { N2c }\end{array}$ & $\begin{array}{l}(54 \%) \\
(18 \%) \\
(22 \%) \\
(6 \%)\end{array}$ \\
\hline $\begin{array}{l}\text { TNM stage } \\
\cdot \text { I } \\
\cdot \text { II } \\
\cdot \text { III } \\
\cdot \text { IV }\end{array}$ & $\begin{array}{ll}2 & (4 \%) \\
15 & (30 \%) \\
12 & (24 \%) \\
21 & (42 \%)\end{array}$ \\
\hline
\end{tabular}

In our study, 15 cases (30\%) showed high Slug expression and 35 (70\%) cases showed low expression. High Slug expression was increased significantly with high tumor grade (Figs. 1 D, E, F), advanced PT stages and high TNM stage (Fig. 2) with a significant difference (p-value $\leq 0.05$ ). Although high Slug expression was observed more frequently in cases with LN metastasis than in cases without LN metastasis, the relation between Slug expression and LN metastasis was statistically insignificant. No significant relationship was observed between Slug expression and tumor site, age and sex of patients (Table 2). 
Immunohistochemical Study of Epithelial Mesenchymal Transition Markers Slug and E-Cadherin...

Table 2: clinicopathological association of Slug expression in laryngeal squamous cell carcinoma

\begin{tabular}{|c|c|c|c|c|c|}
\hline \multicolumn{3}{|c|}{ Clinico Pathological Parameter } & \multicolumn{3}{|c|}{ Slug Expression } \\
\hline Characteristics & NO. & $(\%)$ & Low expression (\%) & High expression (\%) & p-value \\
\hline $\begin{array}{c}\text { Age category } \\
\qquad<60 \\
\cdot>60\end{array}$ & $\begin{array}{l}21 \\
29 \\
\end{array}$ & $\begin{array}{l}(42 \%) \\
(58 \%)\end{array}$ & $\begin{array}{l}17(80.95) \\
18(62.06)\end{array}$ & $\begin{array}{c}4(19.04) \\
11(37.93)\end{array}$ & 0.1504 \\
\hline $\begin{array}{c}\text { Sex } \\
\text { - Male } \\
\text { • Female }\end{array}$ & $\begin{array}{c}48 \\
2 \\
\end{array}$ & $\begin{array}{c}(96 \%) \\
(4 \%)\end{array}$ & $\begin{array}{ll}33 & (68.75) \\
2 & (100)\end{array}$ & $\begin{aligned} & 15(31.25) \\
& 0(0.00) \\
&\end{aligned}$ & 0.3446 \\
\hline $\begin{array}{c}\text { Primary site } \\
\text { - Supraglottic } \\
\text { - Glottic } \\
\text { - Subglottic } \\
\text { - Transglottic } \\
\end{array}$ & $\begin{array}{c}14 \\
12 \\
3 \\
21\end{array}$ & $\begin{array}{l}(28 \%) \\
(24 \%) \\
(6 \%) \\
(42 \%) \\
\end{array}$ & $\begin{array}{ll}8 & (57.14) \\
10 & (83.33) \\
3 & (100) \\
14 & (66.66) \\
\end{array}$ & $\begin{array}{l}(42.85) \\
(16.66) \\
(\mathbf{0 . 0 0}) \\
(33.33) \\
\end{array}$ & 0.3188 \\
\hline $\begin{array}{c}\text { Histological grade } \\
\bullet \text { GI } \\
\bullet \text { GII } \\
\bullet \text { GIII }\end{array}$ & $\begin{array}{l}5 \\
33 \\
12\end{array}$ & $\begin{array}{l}(10 \%) \\
(66 \%) \\
(24 \%)\end{array}$ & $\begin{array}{lr}5 & (100.00) \\
25 & (75.75) \\
5 & (41.66)\end{array}$ & $\begin{array}{ccc} & 0 & (00.00) \\
8 & (24.24) \\
& & (58.33)\end{array}$ & 0.0266 \\
\hline $\begin{array}{c}\text { pT-stage } \\
\bullet \mathrm{T} 1 \\
\bullet \mathrm{T} 2 \\
\bullet \mathrm{T} 3 \\
\bullet \mathrm{T} 4 \\
\end{array}$ & $\begin{array}{c}4 \\
18 \\
17 \\
11 \\
\end{array}$ & $\begin{array}{l}(8 \%) \\
(36 \%) \\
(34 \%) \\
(22 \%)\end{array}$ & $\begin{array}{cc}3 & (75.00) \\
15 & (83.33) \\
13 & (76.47) \\
4 & (36.36) \\
\end{array}$ & $\begin{array}{cc}1 & (25.00) \\
3 & (16.66) \\
4 & (23.52) \\
7 & (63.63) \\
\end{array}$ & 0.0495 \\
\hline $\begin{array}{c}\text { Lymph node metastasis } \\
\qquad \cdot \mathrm{N} 0 \\
\bullet \mathrm{N} 1 \\
\bullet \mathrm{N} 2 \mathrm{~b} \\
\bullet \mathrm{N} 2 \mathrm{c} \\
\end{array}$ & $\begin{array}{l}27 \\
9 \\
11 \\
3\end{array}$ & $\begin{array}{l}(54 \%) \\
(18 \%) \\
(22 \%) \\
(6 \%)\end{array}$ & $\begin{array}{cc}22 & (\mathbf{8 1 . 4 8}) \\
6 & (66.66) \\
6 & (\mathbf{5 4 . 5 4 )} \\
1 & (\mathbf{3 3 . 3 3}) \\
\end{array}$ & $\begin{array}{ll}5 & (18.51) \\
3 & (33.33) \\
5 & (45.45) \\
2 & (66.66) \\
\end{array}$ & 0.1782 \\
\hline $\begin{array}{c}\text { TNM stage } \\
\bullet \text { I } \\
\bullet \text { II } \\
\bullet \text { III } \\
\bullet \text { IV }\end{array}$ & $\begin{array}{c}2 \\
15 \\
12 \\
21\end{array}$ & $\begin{array}{l}(4 \%) \\
(30 \%) \\
(24 \%) \\
(42 \%)\end{array}$ & $\begin{array}{cc}2 & (100.00) \\
12 & (80.00) \\
3 & (25.00) \\
18 & (85.71)\end{array}$ & $\begin{array}{cc}\mathbf{0} & (\mathbf{0 . 0 0}) \\
3 & (20.00) \\
9 & (\mathbf{8 3 . 3 3 )} \\
3 & (\mathbf{1 4 . 2 8 )}\end{array}$ & 0.0013 \\
\hline
\end{tabular}

We detected reduced E-cadherin expression in $58 \%$ of our cases. Reduced E-cadherin expression was significantly associated with high tumor grade (Figs. 1 G, H, I), increased lymph node involvement and high TNM stage (Fig. 3) with a significant difference $(\mathrm{P}$-value $\leq 0.05)$. Reduced E-cadherin expression was found more frequently in advanced pT- stages than in early pT-stages, however, this finding was statistically insignificant. No significant relationship was observed between E-cadherin expression and tumor site, age and sex of patients (Table 3). 
Table 3: clinicopathological association of E-cadherin expression in laryngeal squamous cell carcinoma

\begin{tabular}{|c|c|c|c|c|c|c|c|}
\hline \multicolumn{3}{|c|}{ Clinicopathological parameter } & \multicolumn{5}{|c|}{ E-cadherin Expression } \\
\hline Characteristics & NO. & $(\%)$ & $\begin{array}{r}\text { Reduced exp } \\
(\%)\end{array}$ & ession & $\begin{array}{c}\text { Retained expr } \\
(\%)\end{array}$ & sion & p-value \\
\hline $\begin{array}{c}\text { Age category } \\
\cdot<60 \\
\cdot>60 \\
\end{array}$ & $\begin{array}{l}21 \\
29\end{array}$ & $\begin{array}{l}(42 \%) \\
(58 \%)\end{array}$ & $\begin{array}{l}11(52.38 \\
18(62.06\end{array}$ & & $10\left(\begin{array}{l}(47.61) \\
(37.93)\end{array}\right.$ & 11 & 0.790 \\
\hline $\begin{array}{c}\text { Sex } \\
\text { - Male } \\
\text { - Female } \\
\end{array}$ & $\begin{array}{c}48 \\
2 \\
\end{array}$ & $\begin{array}{c}(96 \%) \\
(4 \%)\end{array}$ & $\begin{array}{l}27(56.25) \\
\quad(100.00\end{array}$ & 2 & $\begin{array}{c}21(43.75) \\
(0.00)\end{array}$ & $\mathbf{0}$ & 0.219 \\
\hline $\begin{array}{l}\text { Primary site } \\
\text { - Supraglottic } \\
\text { - Glottic } \\
\text { - Subglottic } \\
\text { - Transglottic }\end{array}$ & $\begin{array}{c}14 \\
12 \\
3 \\
21\end{array}$ & $\begin{array}{l}(28 \%) \\
(24 \%) \\
(6 \%) \\
(42 \%)\end{array}$ & $\begin{array}{l}\begin{array}{l}10(71.42) \\
(58.33) \\
(33.33) \\
(52.38)\end{array}\end{array}$ & $\begin{array}{l}7 \\
1 \\
11\end{array}$ & $\begin{array}{l}4(28.57) \\
(41.66) \\
(66.66) \\
\quad(47.61)\end{array}$ & $2^{5}$ & 0.5604 \\
\hline $\begin{array}{c}\text { Histological grade } \\
\bullet \text { GI } \\
\bullet \text { GII } \\
\bullet \text { GIII } \\
\end{array}$ & $\begin{array}{l}5 \\
33 \\
12 \\
\end{array}$ & $\begin{array}{l}(10 \%) \\
(66 \%) \\
(24 \%)\end{array}$ & $\begin{array}{l}0(0.00) \\
57.57) \\
\quad(83.33)\end{array}$ & $\begin{array}{l}19( \\
10\end{array}$ & $\begin{array}{c}5(100.00) \\
\quad(42.42) \\
\quad(16.66)\end{array}$ & $2^{14}$ & 0.0065 \\
\hline $\begin{array}{c}\text { T-stage } \\
\bullet \mathrm{T} 1 \\
\bullet \mathrm{T} 2 \\
\bullet \mathrm{T} 3 \\
\bullet \mathrm{T} 4 \\
\end{array}$ & $\begin{array}{c}4 \\
18 \\
17 \\
11\end{array}$ & $\begin{array}{l}(8 \%) \\
(36 \%) \\
(34 \%) \\
(22 \%) \\
\end{array}$ & $\begin{array}{ll}2 & (\mathbf{5 0 . 0 0}) \\
& (55.55) \\
& (41.17) \\
& (90.90)\end{array}$ & $7^{10}$ & $\begin{array}{l}2 \quad(50.00) \\
(44.44) \\
(58.82) \\
\quad(9.09)\end{array}$ & $\begin{array}{r}8 \\
10 \\
1\end{array}$ & 0.0714 \\
\hline $\begin{array}{c}\text { Lymph node metastasis } \\
\bullet \text { N0 } \\
\cdot \text { N1 } \\
\bullet \mathrm{N} 2 \mathrm{~b} \\
\cdot \mathrm{N} 2 \mathrm{c} \\
\end{array}$ & $\begin{array}{l}27 \\
9 \\
11 \\
3\end{array}$ & $\begin{array}{l}(54 \%) \\
(18 \%) \\
(22 \%) \\
(6 \%) \\
\end{array}$ & $\begin{array}{c}10(37.03) \\
(55.55) \\
(100.00) \\
(100.00\end{array}$ & $11^{5}$ & $\begin{array}{c}17(62.96 \\
4(44.44) \\
\quad(0.00) \\
\quad(0.00)\end{array}$ & $\mathbf{0}^{\mathbf{0}}$ & 0.0017 \\
\hline $\begin{array}{c}\text { TNM stage } \\
\bullet \text { I } \\
\bullet \text { II } \\
\bullet \text { III } \\
\bullet \text { IV } \\
\end{array}$ & $\begin{array}{c}2 \\
15 \\
12 \\
21\end{array}$ & $\begin{array}{l}(4 \%) \\
(30 \%) \\
(24 \%) \\
(42 \%)\end{array}$ & $\begin{array}{l}1(50.00) \\
(33.33) \\
(\mathbf{5 0 . 0 0 )} \\
(\mathbf{8 0 . 9 5 )}\end{array}$ & $\begin{array}{r}5 \\
6 \\
17\end{array}$ & \begin{tabular}{l}
$1(50.00)$ \\
$(66.66)$ \\
$(50.00)$ \\
\multicolumn{1}{c}{$(19.04)$}
\end{tabular} & $\begin{array}{c}10 \\
6 \\
4\end{array}$ & 0.0342 \\
\hline
\end{tabular}

The transcriptional repression of E-cadherin is one of the main mechanisms in gene silencing, and Slug plays a pivotal role in this process. In accordance with this data, our study revealed a significant inverse correlation between Slug as EMT inducer and E-cadherin as an epithelial protein in in LSCC (P value $=0.020)$ (Table 4).

\begin{tabular}{|c|c|c|c|c|c|}
\hline \multirow{2}{*}{ SLUG Expression } & \multicolumn{3}{|c|}{ E- cadherin Expression } & \multicolumn{2}{c|}{ Statistical Analysis } \\
\cline { 2 - 4 } & $\begin{array}{c}\text { Reduced } \\
\text { expression }\end{array}$ & $\begin{array}{c}\text { Retained } \\
\text { expression }\end{array}$ & Total & Chi-square & P- Value \\
\hline \multirow{2}{*}{ Low expression } & $\begin{array}{c}24 \\
(82.75 \%)\end{array}$ & $\begin{array}{c}11 \\
(52.38 \%)\end{array}$ & $\begin{array}{c}35 \\
(70 \%)\end{array}$ & & \\
\hline High Expression & $\begin{array}{c}5 \\
(17.24 \%)\end{array}$ & $\begin{array}{c}10 \\
(47.61 \%)\end{array}$ & $\begin{array}{c}15 \\
(30 \%)\end{array}$ & $\mathrm{X}^{2}=5.352$ & $\begin{array}{c}\text { P-value }= \\
0.0206^{*}\end{array}$ \\
\hline Total & $\begin{array}{c}29 \\
(58 \%)\end{array}$ & $\begin{array}{c}50 \\
(42 \%)\end{array}$ & & \\
\hline
\end{tabular}


Table 4: correlation between SLUG and E-cadherin expression

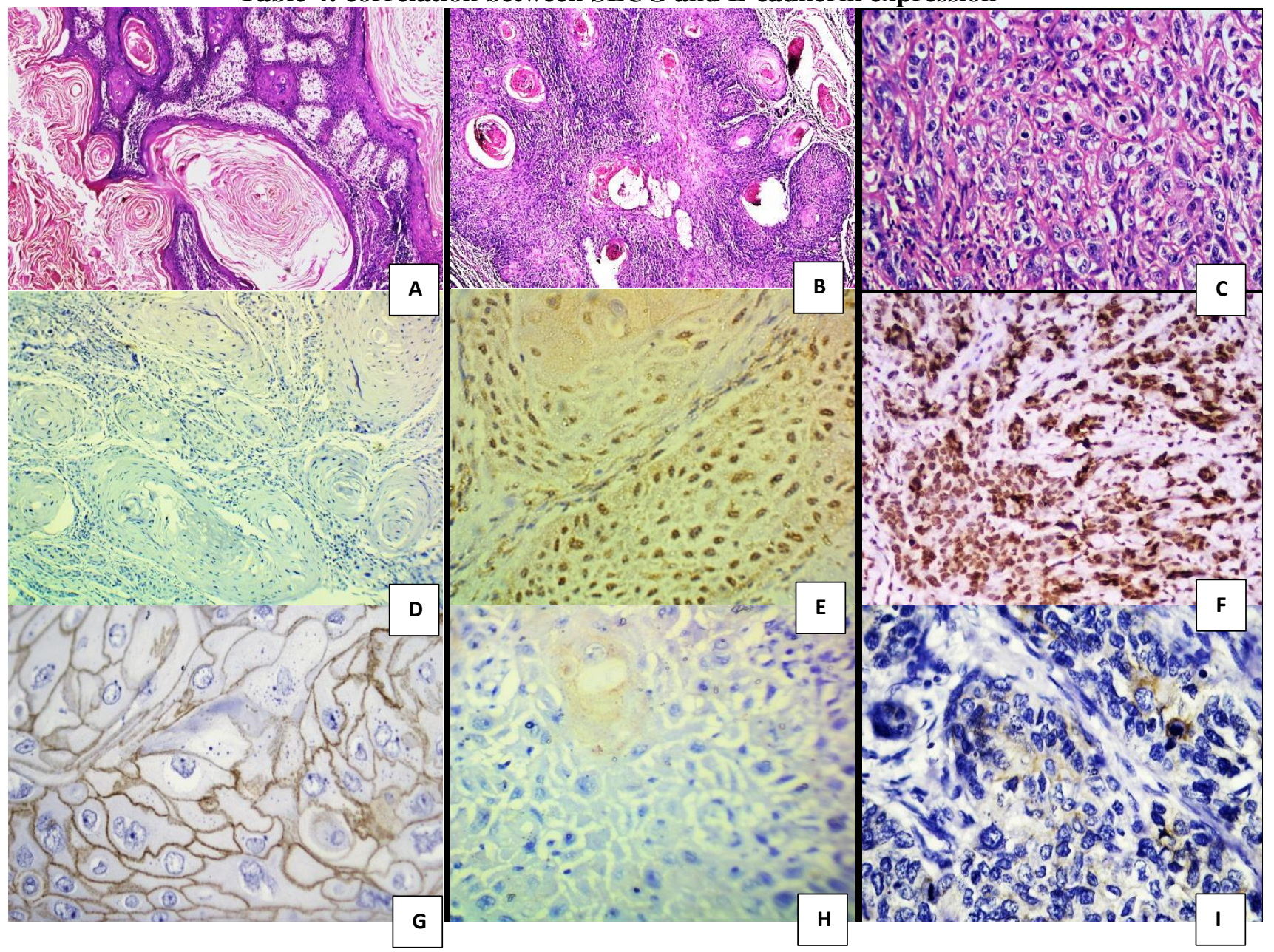

Figure 1 - Laryngeal squamous cell carcinoma, H\&E (A-C), Slug (D-F) and E-cadherin (G-I) immunostaining, ×200: (A, D and G) Well differentiated; (B, E and H) moderately differentiated; (C, F and I) poorly differentiated.

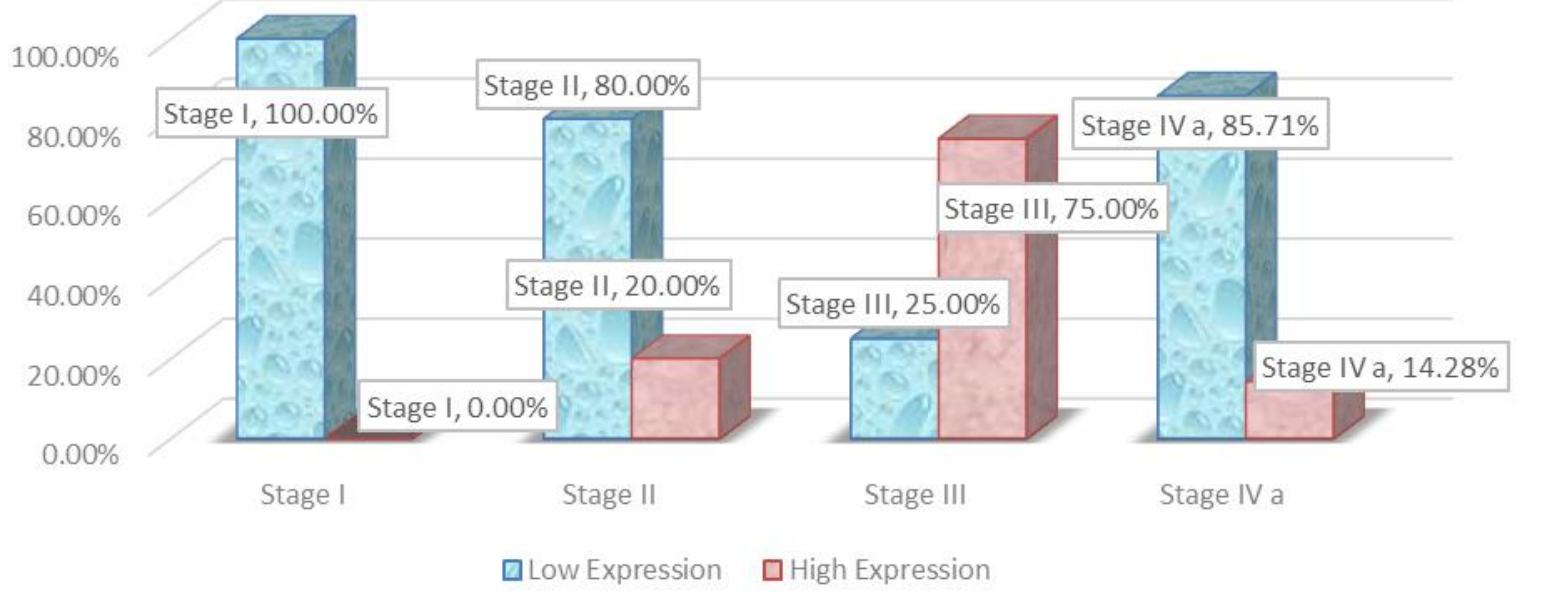

Figure 2: correlation between Slug expression and TNM stage 


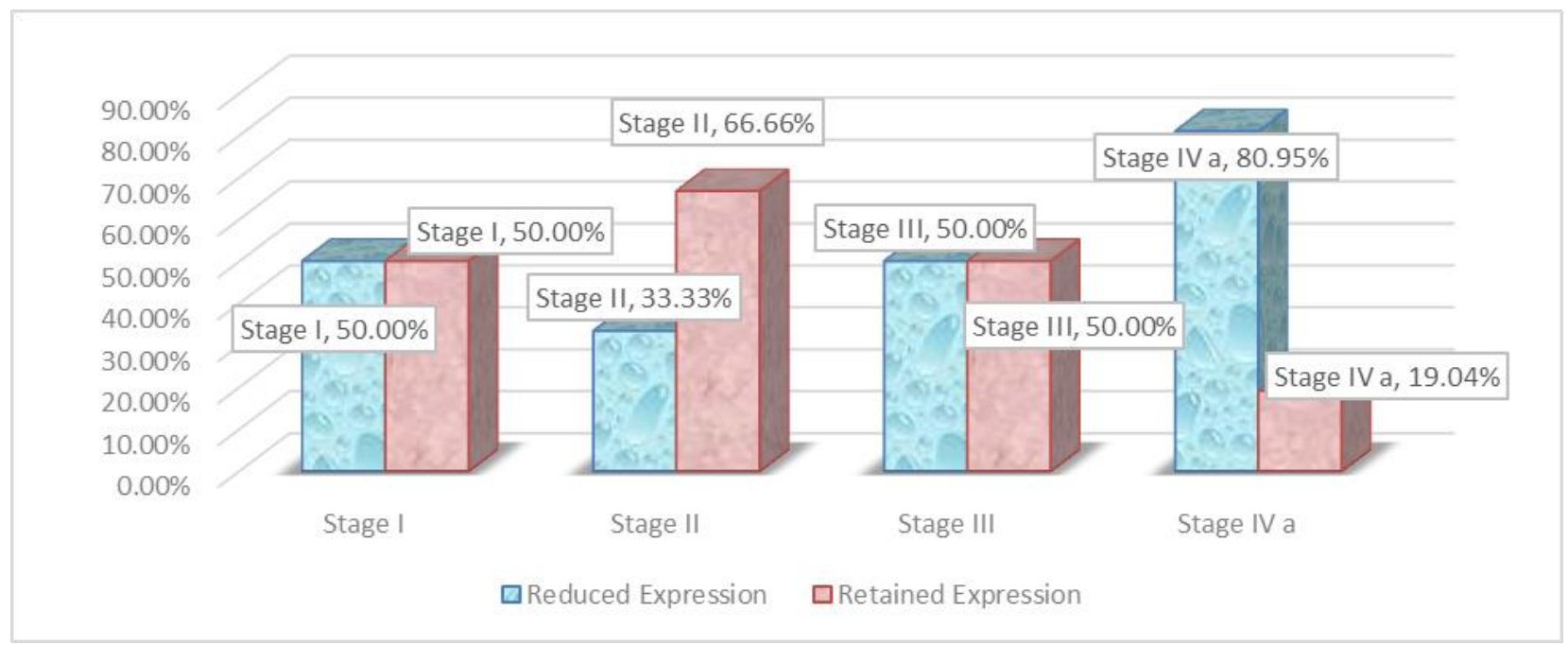

Figure 3: correlation between E-cadherin expression and TNM stage

\section{Discussion}

In the present study, the age of patients ranged from 32 to 75 years, with a mean age of $57.7 \pm 9.74$ SD. These results are close to those of Cercelaru $\boldsymbol{e t}$ al. ${ }^{[10]}$ who reported a mean age of $59.8 \pm 8.0$.Our study showed male predilection, it included 48 males out of 50 cases with a percent of $96 \%$, which is close to the percent reported by Starska et al. ${ }^{[11]}$, as males represented $97.2 \%$, of their studied cases.In the current study, the most common anatomical site for laryngeal carcinoma was transglottic (42\%) followed by supraglottic (28\%), glottic (24\%) and subglottic $(6 \%)$. These results coincide with the study done by Ahmed et al., 2014 ${ }^{[12]}$ that showed the predominance of transglottic tumors.

As regard the modified Broder's grading of laryngeal SCC cases of the current study, most of cases were moderately differentiated $(66 \%)$ followed by poorly differentiated (24\%) and well differentiated (10\%). Similar percentages were reported in the study done by Cercelaru et al. ${ }^{[10]}$ who observed that grade II showed higher prevalence, but showed different percentages among the other histological grades.

Referring to the depth of invasion (pT), twenty eight $(56 \%)$ out of 50 cases were locally advanced (pT3 and pT4), that's near to the percentages in the study done by Akdeniz et al. ${ }^{[13]}$. Regarding the lymph node status, 23 (46\%) patients showed lymph node metastasis, similar percentage was reported in the study done by Larizadeh $\boldsymbol{e t}$ al. [14]. According to staging protocol of laryngeal carcinoma, the current study showed that stage IVa represented $42 \%$ of cases. In the current study, we detected high Slug expression in fifteen $(30 \%)$ and low Slug expression in thirty five $(70 \%)$ of the total studied cases. That's near to the percentage observed by Cappellesso et al. ${ }^{[15]}$, they reported high Slug expression in $24.3 \%$ and low Slug expression in $75.7 \%$ of their studied cases.

According to the obtained data, our results did not suggest the existence of a relation between the Slug expression and the age and sex of the patients. Similarly other study done by Zhang et al. ${ }^{[16]}$ showed no significant correlation as well.

Comparison of Slug immunostaining with the tumor site, showed high Slug expression in $42.85 \%$ of supraglottic cases, $16.66 \%$ of glottic cases and $33.33 \%$ of transglottic cases while all subglottic cases (100\%) showed low Slug expression. Statistical analysis revealed no significant relationship between tumor site and Slug expression. Searching the literature didn't reveal similar studies regarding the correlation between Slug expression and tumor site. In the present study, significant relation between Slug expression and degree of tumor differentiation $(\mathrm{P}$ value $=0.02$ ) was noticed, the reaction being significantly superior in the poorly $(58.33 \%)$ and moderately (24.24\%) differentiated cases compared to the welldifferentiated ones $(0.00 \%)$. These results were consistent with those reported by Starska et al. ${ }^{[11]}$.Evaluation of Slug expression in relation to the infiltration depth of the primary tumor showed significant results $(\mathrm{P}$ value $=0.04)$, where high Slug expression was observed in $39.28 \%$ of locally advanced stages (pT3 andpT4) and in $18.18 \%$ of 
early stages (pT1 and pT2). Our findings agreed with those reported by Starska et al. ${ }^{[11]}{ }^{[11]}$ who reported the presence of significant relation between Slug expression and pT-stage $(\mathrm{P}$ value $=0.001)$. Although, high Slug expression was observed more frequently in cases with LN metastasis $(43.47 \%)$ than in cases without LN metastasis (18.51\%), the relation between Slug expression and LN metastasis was statistically insignificant. Our data are consistent with the study done by Cappellesso et

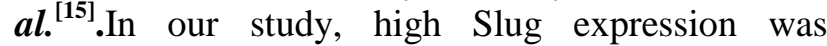
reported in $17.64 \%$ of early stages (I and II) and $36.36 \%$ of advanced stages (III and IV). Statistical analysis revealed highly significant correlation between Slug expression and TNM stage $(\mathrm{P}$ value $=$ 0.001). A similar significant relation between Slug expression and high TNM stage was present in the studies done by Dong et al. ${ }^{[17]}$ and Zhang et al. ${ }^{[16]}$.

The present study showed retained E-cadherin expression in twenty one $(42 \%)$ and reduced Ecadherin expression in twenty nine $(58 \%)$ of the total cases, which is slightly similar to the percentages in the study done by Cappellesso et al. ${ }^{[15]}$.

In our study, no significant correlation was found between E-cadherin expression and either the age or the sex of the patients (p-value, 0.79 and 0.21). This is supported by results of Cercelaru et al. ${ }^{[10]}$.In considering the relationship between the tumor site and E-cadherin expression, we found retained E-cadherin expression in $28.57 \%$ of the supraglottic cases, $41.66 \%$ of the glottic cases, $66.66 \%$ of the subglottic cases and $47.61 \%$ of the transglottic cases, while reduced E-cadherin expression was observed in $71.42 \%$ of the supraglottic cases, $58.33 \%$ of the glottic cases, $33.33 \%$ of the subglottic cases and $52.38 \%$ of the transglottc cases. Our results showed no significant correlation between the tumor site and E-cadherin expression in concordance with some studies ${ }^{\left[\mathbf{1 8}^{\prime} 19\right]}$ .They did not show any significant correlation between the tumor site and E-cadherin expression. Among the studies that evaluated the correlation of the reduction of E-cadherin expression with the tumor site, only Ahmed et al. ${ }^{[12]}$ found significant change when observing less expression of Ecadherin $(p=0.002)$ at the supraglottic site.

When the degree of histological differentiation was evaluated in relation to Ecadherin expression, there was a statistically significant association $(\mathrm{P}$ value $=0.006)$. Reduced E-cadherin expression was noted more frequently in poorly differentiated $(83.33 \%)$ and moderately differentiated $(57.57 \%)$ cases in comparison to the well differentiated cases $(0.00 \%)$. The significant correlation between E-cadherin immunoreaction and the tumor grade was also signaled by Larizadeh $\boldsymbol{e t}$ al. ${ }^{[14]}$ and Akdeniz et al. ${ }^{[13]}$.Comparison of Ecadherin immunostaining with the pT-stage, showed retained E-cadherin expression in $39.28 \%$ and $45.45 \%$ of advanced pT- stages (T3 and T4) and early pT-stages (T1 and T2) respectively. Although the expression of E-cadherin in the advanced $\mathrm{pT}$ stages was lower than in the early pT-stages, the results are near statistically significant $(\mathrm{P}$ value $=$ 0.0714). These results are matching with those obtained by Greco et al. ${ }^{[18]}$ and Cercelaru et al ${ }^{[10]}$. In the present study, reduced E-cadherin expression was observed in $37.03 \%$ of cases without $\mathrm{LN}$ metastasis and $82.61 \%$ of cases with LN metastasis, with a significant difference $(\mathrm{P}$ value $=0.001)$. Our data are consistent with studies done by Larizadeh et al. ${ }^{[14]}$ and Zhu et al. ${ }^{[19]}$.

In our study, E-cadherin expression was correlated with high TNM stage with a significant difference ( $p$-value <0.05), where retained Ecadherin expression was detected most frequently in stage I-II $(64.7 \%)$ than in stage III-IV $(30.30 \%)$. A similar significant inverse relation between Ecadherin expression and highTNM stage was present in the studies done by Zvrko et al. ${ }^{[20]}$ and Ahmed et al. ${ }^{[12]}$. The present study demonstrated a significant inverse correlation between Slug as EMT inducer and E-cadherin as an epithelial protein in in LSCC $(\mathrm{P}$ value $=0.020)$. This result agrees with those Dong et al. ${ }^{[17]}$ and Zhang et al. ${ }^{[16]}$ who concluded that patients with high Slug expression displayed reduced E-cadherin expression with a significant relationship between Slug overexpression and reduced E-cadherin expression ( $\mathrm{p}$-value $<0.005$ ).

\section{Conclusion}

We concluded that EMT is implicated in LSCC worsening the prognosis. Thus Slug and Ecadherin IHC determination could be useful in predicting the clinical outcome of LSCC and identifying patients at higher risk of metastasis who might benefit from more aggressive treatment.

\section{References}

1-Cho I, Lee M, Lim S and Hong $R$ (2016): Significance of parafibromin expression in laryngeal 
squamous cell carcinomas. Journal of Pathology and Translational Medicine, 50: 264-269.

2-Jemal A, Siegel R, Xu J and Ward E (2010): Cancer statistics. J. Clin., 60: 277-300.

3- Song FC, Yang $Y$ and Liu JX (2016): Expression and significances of MiRNA Let-7 and HMGA2 in laryngeal carcinoma. European Review for Medical and Pharmacological Sciences, 20: 4452-4458.

4-Li L, Wang J, Gao $L$ and Gong $L$ (2015): Expression of paxillin in laryngeal squamous cell carcinoma and its prognostic value. Int. J. Clin. Exp. Pathol., 8: 9232-9239.

5-De Santis CE, Lin CC, Mariott o AB, Siegel RL, Stein KD, Kramer JL, Alt eri R, Robb ins AS and Jemal A (2014): Cancer treatment and survivorship statistics. Cancer J. Clin., 64: 252-271.

6- Liua S, Shid L, Wanga Y, Yea D, Jua H, Maa $H$, Yanga $W$, Wanga $Y$, Hua $J$, Denge $J$ and Zhanga $Z$ (2018): Stabilization of Slug by NF- $\kappa B$ is essential for TNF- $\alpha$-induced migration and epithelial-mesenchymal transition in head and neck squamous cell carcinoma cells cell physiol. Biochem.,47: 567-578.

7-Lee HH, Lee SH, Song KY, Hyun J, Park JM, Jung ES, Choi M and Park CH (2017): Evaluation of Slug expression is useful for predicting lymph node metastasis and survival in patients with gastric cancer. BMC Cancer, 17:670-677.

8-Dong G, Yongdo N and Lim S (2010): Relation between pro-inflammatory mediators and epithelialmesenchymal transition in head and neck squamous cell carcinoma. Experimental and Therapeutic Medicine, 1: 885-891.

9-Galera-Ruiz H, R'ios-Moreno MJ and Gonz'alez- C'ampora R (2012): The cadherincatenin complex in laryngeal squamous cell carcinoma. European Archives of Otorhinolaryngology, 269 (4):1183-1188.

10- Cercelaru L, Stepan A, Mărgăritescu C, Osman A, Popa I, Florescu M, Simionescu C and Mărgăritescu O (2017): E-cadherin, $\beta$-catenin and Snail immunoexpression in laryngeal squamous cell carcinoma. Rom. J. Morphol. Embryol., 58(3):761766.

11- Starska K, Forma E, Lewy-Trenda I, Papież P, Woś $J$ and Bryś M (2013): Diagnostic impact of promoter methylation and E-cadherin gene and protein expression levels in laryngeal carcinoma. Wspolczesna Onkol., 17 (3): 263-271.

12- Ahmed RA, Shawky A and Hamed RH (2014): Prognostic Significance of Cyclin D1 and Ecadherin Expression in Laryngeal Squamous Cell Carcinoma. Pathol. Oncol. Res., 20:625-633.

13- Akdeniz O, Akduman D, Haksever M, Ozkarakas H and Müezzinoglu B (2013): Relationships between clinical behavior of laryngeal squamous cell carcinomas and expression of VEGF, MMP-9 and E-Cadherin. Asian Pac. J. Cancer Prev., 14: (9): 5301-5310.

14- Larizadeh MH, Damghani MA, Tabrizchi H and Mirshekari TR (2009): Expression of Ecadherin in squamous cell carcinoma of the larynx and its correlation with clinicopathological features. Journal of Medical Sciences, 9 (1): 41-45.

15- Cappellesso R, Marioni G, Crescenzi M, Giacomelli L, Guzzardo V, Mussato A, Staffieri A, Martini A, Blandamura $\mathbf{S}$ and Fassina A (2015): The prognostic role of the epithelial-mesenchymal transition markers E-cadherin and Slug in laryngeal squamous cell carcinoma. Histopathology, 67: 491-500.

16- Zhang J, Cheng $\mathbf{Q}$, Zhou Y, Wang $Y$ and Chen X (2013): Slug is a key mediator of hypoxia induced cadherin switch in HNSCC: Correlations with poor prognosis. Oral Oncology, 49: 1043-1050. 17- Dong G, Yongdo $N$ and Lim $S$ (2010): Relation between pro-inflammatory mediators and epithelial-mesenchymal transition in head and neck squamous cell carcinoma. Experimental and Therapeutic Medicine, 1: 885-891.

18- Greco A, De Virgilio A, Rizzo M, Pandolfi F, Rosati $D$ and de Vincentiis $M$ (2016): The prognostic role of E-Cadherin and b-Catenin overexpression in laryngeal squamous cell carcinoma. Laryngoscope, 126:148-155.

19- Zhu G, Song P, Zhou H, Shen X, Wang J, Liu D, Feng A, Qian X and Gao X (2018): Role of epithelial-mesenchymal transition markers Ecadherin, $\mathrm{N}$-cadherin, $\beta$-catenin and ZEB2 in laryngeal squamous cell carcinoma. Oncology Letters, 15: 3472-3481.

20- Zvrko E, Miki A and Jancic S (2012): Relationship of E-cadherin with cervical lymph node metastasis in laryngeal cancer. Coll. Antropol., 36 (2): 119-124. 